\title{
VALUES, ENVIRONMENTAL CONCERN AND ECONOMIC CONCERN AS PREDICTORS OF ENTERPRISE ENVIRONMENTAL RESPONSIVENESS
}

\section{Vojko POTOCAN ${ }^{1}$, Zlatko NEDELKO², Valentina PELECKIENË $\dot{3}^{3}$, Kęstutis PELECKIS ${ }^{4}$}

\author{
${ }^{1,2}$ Department of Management and Organization, Faculty of Economics and Business, \\ University of Maribor, Razlagova 14, 2000 Maribor, Slovenia \\ ${ }^{3}$ Department of Social Economics and Management, Business Management Faculty, Vilnius \\ Gediminas Technical University, Sauletekio al. 11, LT-10223, Vilnius, Lithuania \\ ${ }^{4}$ Department of Economics and Management of Enterprises, Business Management Faculty, \\ Vilnius Gediminas Technical University, Sauletekio al. 11, LT-10223, Vilnius, Lithuania \\ E-mails: ${ }^{1}$ vojko.potocan@um.si (corresponding author); \\ 2zlatko.nedelko@um.si; ${ }^{3}$ valentina.peleckiene@vgtu.lt; ${ }^{4}$ kestutis.peleckis@vgtu.lt
}

Received 25 May 2016; accepted 13 June 2016

\begin{abstract}
This article reports on examination of the relationships between manager's personal values, their attitudes toward concern for environment, concern for economic results and enterprise environmental responsiveness. Schwartz's list of values and statements about the environmental and economic concerns is used. We analyzed 1179 managers' answers from Slovenian enterprises with structural equation modeling. Manager's concern results: (a) for environment positively and significantly and (b) for economics negatively and insignificantly, in influence on enterprise environmental responsiveness. Two value dimensions significantly influence enterprise environmental responsiveness and one negatively. Environmental concern mediates the effect of three, and concern for economic results mediates the effect of two value dimensions on enterprise's environmental responsiveness. Generalization can be limited due to the focus on one Central Europe country; future examination is needed. Findings are useful for the development of enterprises' pro-environmental behavior and development of enterprise value system. A model of enterprise's environmental responsiveness is developed.
\end{abstract}

Keywords: attitude, economic, environment, enterprise, values, responsiveness.

JEL Classification: A13, C30.

\section{Introduction}

Numerous management solutions have emerged in recent years for improving the enterprises' working and behavior regarding their relations to the natural environment (NE) (Alibeli, Johnson 2009; Glavas, Kelley 2014; Gonzalez-Rodriguez et al. 2016). At the same time, there are limited research evidences how employees' personal values (PV) 
and employees' attitudes influence the enterprises relations to NE (Cordano et al. 2010; Wang, Juslin 2011; Wynder, Dunbar 2016).

Modern enterprises are faced with the dilemma how to achieve several goals - i.e. economic, natural, social, and ethical goals (Baumol et al. 2007; Peet, Hartwick 2008; Mullins 2013). Therefore, literature emphasized diversified management concepts, which are focused on protection and improvement of NE (Blackburn 2007; Haq, Alistair 2011).

The social and environmentalism studies of enterprises' offer limited insights into enterprises' behaviour factors, which determine enterprises' relationship to NE (Dunlap et al. 1993; Raven, Berg 2003; Davis et al. 2008; Gonzalez-Rodriguez et al. 2016). The economic, business and management authors emphasized importance of environmental protection in business, but the necessary changing of business behavior is dealt with separately (Thompson, Barton 1994; Sullivan 2011). In forefront of environmental management are studies about pro-environmental behavior, environmental values and attitudes, and social responsibility (Westing 1996; Singhapakdi et al. 1996; Vitell et al. 2010). Just individual studies emphasized the influence of economic viewpoints on enterprises' environmental orientation (Raven, Berg 2003; Baumol et al. 2007; Sullivan 2011) as necessary balanced trade-off between economic and environmental goals of enterprises (Agle et al. 1999; Raven, Berg 2003; Baumol et al. 2007; Sullivan 2011). The relationship of enterprises to NE is importantly determined by the behavior factors - i.e. beliefs, values, attitudes, etc. (Schwartz 1994; Marcus et al. 2015). Management authors examine values on the base of different methodological starting points for definition of values and behavior - like value-based theory (Rokeach 1973; Schwartz 1994; Hofstede 2001).

Management literature reported about direct and indirect consideration of values and their influences on enterprises' pro-environmental behavior (Schwartz et al. 2012; Ralston et al. 2014; Gonzalez-Rodriguez et al. 2016). We followed authors, which originate work in values-attitudes-behavior chain (Schwartz 1994; Ralston et al. 2011; Glavas, Kelley 2014). With use of Schwartz' Theory of basic human values (Schwartz 1994) we define ten groups of personal values (PV) that are expected to shape managers' attitudes toward the enterprise environmental responsiveness (EER).

Our research reduces the gap between the well spread theoretical researches and less many empirical evidences about influence of managers' PV and managers' attitudes toward environmental and economic concern for EER.

\section{Theoretical framework and hypotheses development}

Literature reported about different relationships between enterprises and NE (Ralston et al. 2011; Camelo-Odraz et al. 2012; Glavas, Kelley 2014). The management theory classifies theoretical and practical cognitions about this issue into two groups (Cordano et al. 2010; Trevino et al. 2014).

The first group includes economic, business, and management studies that are focused on relationships between enterprises and NE through consideration of green business theories (Davis et al. 2008; Peet, Hartwick 2009). These studies reported about va- 
riety of business goals, needs to balance between them, human impacts on business, and mezzo organizational theories (Blackburn 2007; Mullins 2013). The second group includes sociological studies, which are focused on the EER and originate in environmentalism (Raven, Berg 2003; Haq, Alistair 2011). They reported about protection of natural resources and ecosystems, the need for the development of suitable behavior of enterprises, and the influence of employees' PV on development of their ATEN (Stern, Dietz 1994; Karp 1996; Schultz et al. 2005).

We originate our work in studies about enterprises' responsible behavior with the research of influence of managers' attitudes toward EER in the framework of valuesattitudes-behavior theory (VABT) (Dunlap et al. 1993; Schultz, Zelezny 1999). In that framework, EER was defined as enterprises' awareness of environmental issues and their utilization of responsible working and behavior about NE (Schultz et al. 2005; Oreg, Katz-Gerro 2006). Following the tradition of social psychology (Jung 1921; Wood 2000; Ajzek 2001), we treat attitudes as "a psychological tendency that is expressed by evaluating a particular entity with some degree of favor or disfavor" (Schwartz 1994; Schwartz et al. 2012).

Despite several studies, there is in literature only limited evidence about influence of employees' ATEN on EER (Davis et al. 2008; Camelo-Odraz et al. 2012; Wynder, Dunbar 2016). ATEN are based on the relative importance that persons place on themselves, other people, or plants and animals; several authors labeled this as egoistic, social-altruistic, and bio-spheric values orientation (Schultz, Zelezny 1999; Stern 2000; Schultz et al. 2005). Environmental studies reported that employees' ATEN contains valid predictors for EER (Schultz, Zelezny 1999; Haq, Alistair 2011). These arguments suggest the following hypothesis:

H1: Managers attitudes toward concern for environment are significantly and positively related to the enterprise environmental responsiveness.

ATEC are based on the relative importance that persons ascribe to the achievement of the economic results on their, others', or society working (Dunlap et al. 1993; Karp 1996; Schwartz et al. 2012). Recent studies offer limited insights in relations between ATEC as worrying of employees about the economic results of enterprise, and EER (Baumol et al. 2007; Hanley et al. 2007; Cordano et al. 2010). Following the tradition of classical economics we presume negative relations between managers' ATEC and EER (Friedman 1970; Hanley et al. 2007). These arguments suggest the following hypothesis:

H2: Managers attitudes toward concern for economic results are significantly and negatively related to the enterprise environmental responsiveness.

Studies of VABT do not clearly explain the influence of individual's PV on their attitudes (Posner, Munson 1979; Papagiannakis, Lioukas 2012). Values are conceptualized as important life goals or standards which serve as guiding principles in a person's life (Rokeach 1973; Schwartz 1994). While the significance of employees' PV in studying of enterprises' working has been noted, the mechanism by which PV impact organizations is not clearly understood (Ralston et al. 2011; Glavas, Kelley 2014). Present studies emphasize values as determinants of attitudes and behaviors (Posner, Munson 
1979; Schultz, Zelezny 1999; Ralston et al. 2014); they used for their consideration different social-psychological paradigms - like values-base theory (Stern, Dietz 1994; Stern 2000; Dietz et al. 2005).

The reported research examines values with use of Schwartz' cognitions (Schwartz 1994; Schwartz et al. 2012) and adopted his typology of PV. The prior studies which originate in Schwartz' work (Schwartz 1994) examine PV of individuals as valuesitems, types and categories of values' system and confirmed influences of different values types on organizational behavior (Karp 1996; Nordlund, Garvill 2002; Stern, Dietz 1994; Dietz et al. 2005). Thus, we presume that ten values types of individual PV significantly influence the: (a) considered employees' ATEN and ATEC, and (b) EER. These arguments suggest the following hypotheses:

H3: Managers' personal values significantly influence managers' attitudes toward the concern for natural environment.

H4: Managers' personal values significantly influence managers' attitudes toward the concern for economic results.

H5: Managers' personal values significantly influence enterprise environmental responsiveness.

Management studies also reported contradictory results about the mediating role of diverse factors with influence of PV on behavior (Agle et al. 1999; Dietz et al. 2005; Alibeli, Johnson 2009). Several studies reported that diversified factors mediate the effect of values on behavior - e.g. influence of culture (Hofstede 2001; Shafer et al. 2007); ethics (Glavas, Kelley 2014; Trevino et al. 2014), personality (Oreg, Katz-Gerro 2006; Mullins 2013). Studies of VABT also reported about important mediating role of attitudes on influence of PV on behavior - e.g. in international and national studies (Shafer et al. 2007; Pastor, Mayo 2008; Cordano et al. 2010). According to the mentioned studies, we presume that personal attitudes mediate the effect of PV on EER. These arguments suggest the following hypotheses:

H6: Managers attitudes about concern for natural environment mediate the effect of their personal values on the enterprise environmental responsiveness.

H7: Managers attitudes about concern for economic results mediate the effect of their personal values on the enterprise's environmental responsiveness.

\section{Methodology}

\subsection{Sample and procedure}

Random sampling was done based on GVIN, a directory which lists Slovenian business organizations (Bisnode 2016). Data were collected through computer-assisted telephone interviews (CATI) of employees in Slovenian organizations in 2015. A maximum three answers per organization were allowed. 1000 organizations and around 3500 managers in the selected organizations were contacted. We obtained 1214 answers, resulting in $34.7 \%$ response rate. After elimination of incomplete answers and several including outliners, our sample includes 1179 answers. 
In terms of sample characteristics we outline the following. The average age of managers is 38.7 years and managers have on average 16.1 years of work experiences. Among them 38\% are males and 62\% are females. Regarding participants': (1) education, 39.5\% have finished high school, $45.9 \%$ have bachelor degree, and the rest have master $(11.7 \%)$ and doctorate $(2.6 \%)$ degree; and (b) current position in the organization, $52.7 \%$ are first-line managers, $31.0 \%$ are middle managers, and $16.3 \%$ are top managers. In terms of organizational size, $58.6 \%$ of managers' work in organizations with fewer than 100 employees, $31.6 \%$ in organizations having between 100 and 1000 employees, and $10.1 \%$ in organizations with more than 1000 employees. The managers were from organizations operating in agriculture, mining, forestry and fishing $(1.7 \%)$, construction $(3.0 \%)$, manufacturing $(24.4 \%)$, transportation and communication $(8.7 \%)$, the wholesale and retail trade $(18.3 \%)$, finance, insurance, and real estate $(12.7 \%)$, services $(8.7 \%)$, public administration $(11.2 \%)$, healthcare $(2.4 \%)$, and other industries $(8.6 \%)$.

Instrument used - Questionnaire for this survey was composed from different questionnaires and consists of three parts. In the first part we included a list of values from Schwartz's value survey (Schwartz 1994); in the second part 25 items aimed to measure different aspects of enterprises' social responsibility and related social responsible behavior from international research groups were adopted (Ralston et al. 2011; Ralston et al. 2014). In the last part we asked participants about typical demographic data in business research.

\subsection{Measures}

Personal values - Schwartz value survey (SVS) was used to measure employees' PV (Schwartz 1994). SVS is a broadly used cross-culturally validated questionnaire, including a list of $56 \mathrm{PV}$, which are aimed to measure ten motivational types that guide human behavior. 56 single values can be further collected into 10 groups of PV (also named dimensions of value) which were used in this study. Their reliability were assessed on worldwide samples in psychological research stream (Schwartz 1994), business research (Schultz, Zelezny 1999; Nordlund, Garvill 2002; Ralston et al. 2011), as well as on Slovenian samples (Potocan et al. 2013; Potocan, Nedelko 2015). In this paper dimensions of values have the following reliability: power $(\alpha=.695)$, achievement $(\alpha=.714)$, hedonism $(\alpha=.645)$, stimulation $(\alpha=.628)$, self-direction $(\alpha=.599)$, universalism $(\alpha=.783)$, benevolence $(\alpha=.742)$, security $(\alpha=.597)$, tradition $(\alpha=$ $.581)$, and conformity $(\alpha=.603)$. The obtained reliability coefficients are comparable to those in business studies using Schwartz' SVS (Ralston et al. 2011; Potocan et al. 2013; Potocan, Nedelko 2015).

Managers' attitudes - Managers' ATEN and ATEC, were measured with 25 items aimed at measuring EER (Blackburn 2007; Cordano et al. 2010; Ralston et al. 2011). ATEN is accurately and reliably represented by four items - i.e. EN1, EN2, EN3, and EN4 (see e.g. Dunlap et al. 1993; Thompson, Barton 1994; Cordano et al. 2010). Cronbach's $\alpha$ for this scale was 0.736 . The reliability of the construct "managers' environmental concern" could be compared with the "environmental concepts" presented by researchers 
in this field. For instance, research about the level of environmental concern (Alibeli, Johnson 2009) illustrates a Cronbach's $\alpha$ falling between 0.539 and 0.572 for three constructs related to concern for the environment. Schultz and Zelezny (1999) reported a Cronbach's $\alpha$ coefficient between 0.47 and 0.81 ; after modification, the reliability coefficient for all 14 nations in the sample was 0.70 . In this field of research, Nordlund and Garvill (2002) and Oreg and Katz-Gerro (2006) reported similar values of Cronbach's $\alpha$ (the lowest $\alpha=0.52$ and $\alpha=0.50$, respectively). Thus, it is evident that reliability of environmental concern is in line with those reported in the above outlined environmental behavior studies. Managers' ATEC is accurately and reliably represented with items used to measure the importance of achieving economic results. For our consideration of ATEC we used 6 items - i.e. EC1, EC2, Ec3, EC4, EC5, and EC6 (see e.g. Kemmelmeier et al. 2002; Blackburn 2007; Mullins 2013). Cronbach's $\alpha$ for this scale was 0.611. In our research the ATEC yielded a lower reliability coefficient, in comparison to environmental concern. Looking for the reasons for relatively low achieved reliability, reveals different approaches in studying "profit orientation", which is mainly oriented on well-established instruments and on the organizational level. For instance, a survey that is focused on issue regarding justification of enterprises' social responsibility in organizations, does not report about reliability coefficients, since the accounting-based measures are utilized - e.g. return on assets, return on equity, etc. (Agle et al. 1999; Lin et al. 2012). There are also other studies, which do not report about reliability coefficients of economic aspects, due to the nature of the study - primarily theoretical orientation of the studies (Munda 1997; Hanley et al. 2007; Mullins 2013). In our study we examine the economic aspect of enterprise's social responsibility through the lenses of managers' ATEC. In search for dimensions or constructs aimed to measure "profit or economic orientation", we emphasize a research about managers orientation, where Cronbach's $\alpha$ for performance goal orientation was 0.61 (Pastor, Mayo 2008). According to the outlined cognitions about economic dimension of EER and its empirical measurement, we can conclude that reliability of ATEC is in acceptable range, according to the prevalent practice in this field and the exploratory nature of the study. Enterprises' environmental responsiveness - finally, we identified a construct focusing on managers' perception of EER. The used four items for measuring measure this construct - i.e. RES 1, RES2, RES3, and RES 4 (see e.g. Westing 1996; Cordano et al. 2010). Cronbach's $\alpha$ for this scale was 0.659 . Again, reliability coefficient is acceptable due to the exploratory nature of the study. Our reliability is comparable with those in similar studies in this field (Schultz, Zelezny 1999; Nordlund, Garvill 2002) as well as to the different business research about employees' and managers' behavior (Ralston et al. 2011; Ralston et al. 2014).

\subsection{Research design and data analysis}

We examined the relationships among managers' PV, managers' ATEN and ATEC, and EER, as perceived by the managers. Structural equation modeling (SEM) techniques were used to examine these relations. Hypotheses were tested using AMOS program, following the suggestions of Arbuckle (2007) and Byrne (2010). Elements of descriptive statistics and zero-ordered correlations for variables used in the study were also outlined. 


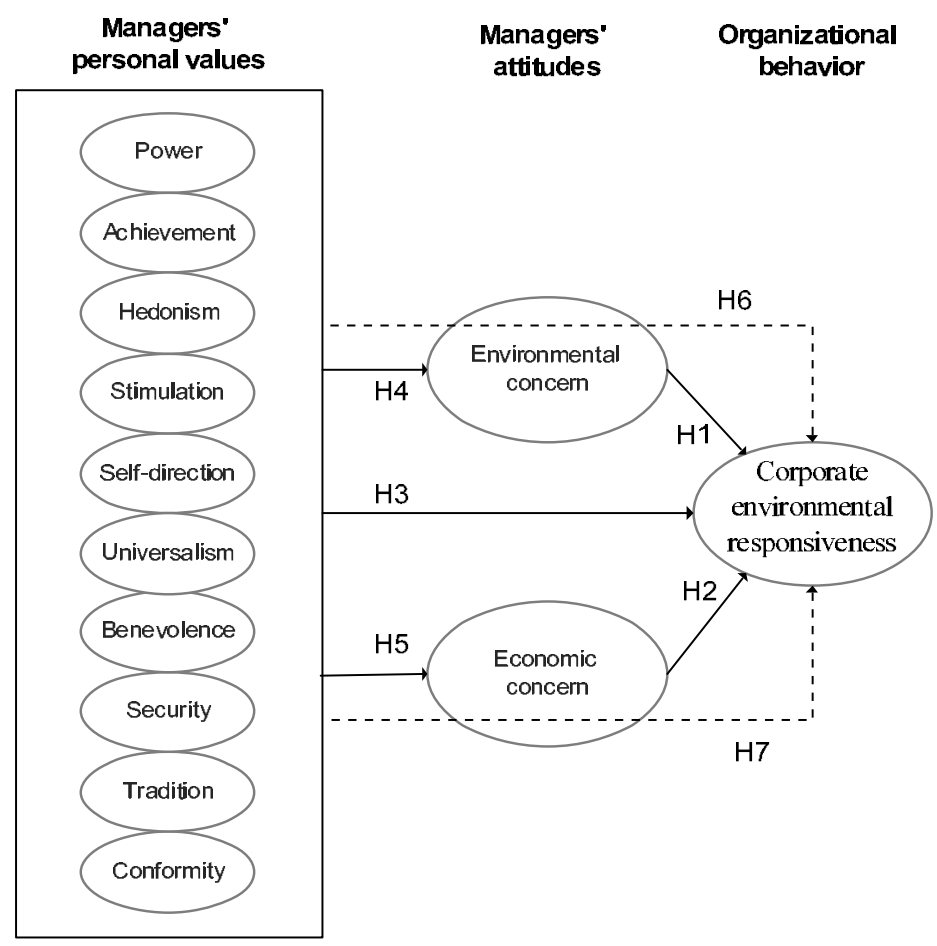

Fig. 1. Research model

Source: designed by authors.

First, the impact of managers' ATEN and ATEC on EER was examined. Second, the impact of ten dimensions of PV on managers' ATEN and ATEC was examined, and followed by the impact of personal values on EER. In the last step, one examined the mediation effect of managers' ATEN and ATEC on the association between managers' personal values and EER, as perceived by the managers. Before testing the mediation effect one examined conditions for existence of mediation effect (Baron, Kenny 1986; Zhao et al. 2010). Research model for our work is depicted in Figure 1.

\subsection{Analysis of the proposed research model}

Prior to hypotheses testing we test the fit of the proposed model. Our research approach is built upon: (1) prevalent practice in environmental research stream, where focus is to identify significant pathways between PV and designated constructs, often not considering the reliability of the entire proposed model or possible relations (Schultz, Zelezny 1999; Nordlund, Garvill 2002); (2) general findings from psychological literature about relations between values, attitudes and behavior in the frame of value-attitude-behavior theory (Rokeach 1973; Homer, Kahle 1988; Schwartz 1994); and (3) experiences from individual studies which examine PV and their relations to different attitudes and behaviors (Kemmelmeier et al. 2002; Papagiannakis, Lioukas 2012; Potocan et al. 2013). In terms of reporting goodness of fit of the proposed research model (Fig. 1), the fit 
statistics was calculated for the three factor measurement model - i.e. ATEN, ATEC, and EER. The fit statistics for three factor measurement model $\left(\chi^{2}(\mathrm{~N}=1179\right.$, df $=69)=$ 325.391, $\mathrm{p}<.05$; CFI = .915; IFI = 0.916; RMSEA = .056; PCLOSE $<.05$ (0.047) indicated a good fit between the hypothesized model and data (Hu, Bentler 1999; Byrne 2010). Thus, for the final model it was presupposed that our proposed model will reflect the data well, when significant pathways between PV and environmental constructs were confirmed in different studies (Schultz, Zelezny 1999; Shafer et al. 2007; Wang, Juslin 2011), including the reliable factorial structure of the Schwartz personal values theory (Schwartz 1994).

Multicollinearity - in terms of identifying multicollinearity among managers' PV, managers' ATEN, managers' ATEC and EER, the "tolerance values" ranged between 0.372 and 0.808 , and the VIF values ranged between 1.237 and 2.691 According to Ho's (2006) suggestions, tolerance values, greater than 0.10 and VIF values lower than 10 are all acceptable. Thus, multicollinearity is not an issue in our analysis.

\section{Research results}

\subsection{Analysis of the results}

Descriptive statistics and zero-order correlations for the variables of interest in the study are shown in Table 1. These findings suggest a deeper examination of the association between manager's PV, managers' ATEN, managers' ATEC, and EER.

Table 2 presents path analysis of considered managers' attitudes on EER.

Table 2 reveals that managers' ATEN are significantly and positively related to the EER $(\beta=0.872, p<.001)$. This result confirms the Hypothesis 1 . Table 2 also reveals that managers' ATEC are insignificant and negatively related to the EER $(\beta=-0.010, p>$ .05). Because the managers' ATEC are insignificant, we reject Hypothesis 2.

Table 3 presents the direct effect of dimensions of personal values on ATEN, ATEC, and EER.

Results in Table 3 reveal that managers' PV universalism, benevolence, and conformity are significantly and positively related to their ATEC, while power, achievement, hedonism, and tradition are significantly and negatively related to their ATEN. The impact of managers' PV stimulation, self-direction, and security are not significant. Based on findings about the significant impact of seven managers' PV, we can support Hypothesis 3. In terms of explained variance, results show that $29.9 \%$ of the variance in managers' ATEN is accounted for by the variance in managers' PV.

Table 3 reveals that power, achievement, hedonism, and tradition are significantly and positively related to managers' ATEC, while self-direction, universalism, and benevolence are significantly and negatively related to their ATEC. Additionally, the impact of managers' PV stimulation and conformity are not significant. Based on findings about the significant impact of seven managers' PV we can support Hypothesis 4. In terms of the explained variance, results show that $36.3 \%$ of the variance in managers' ATEC is accounted for by the variance in managers' PV. 


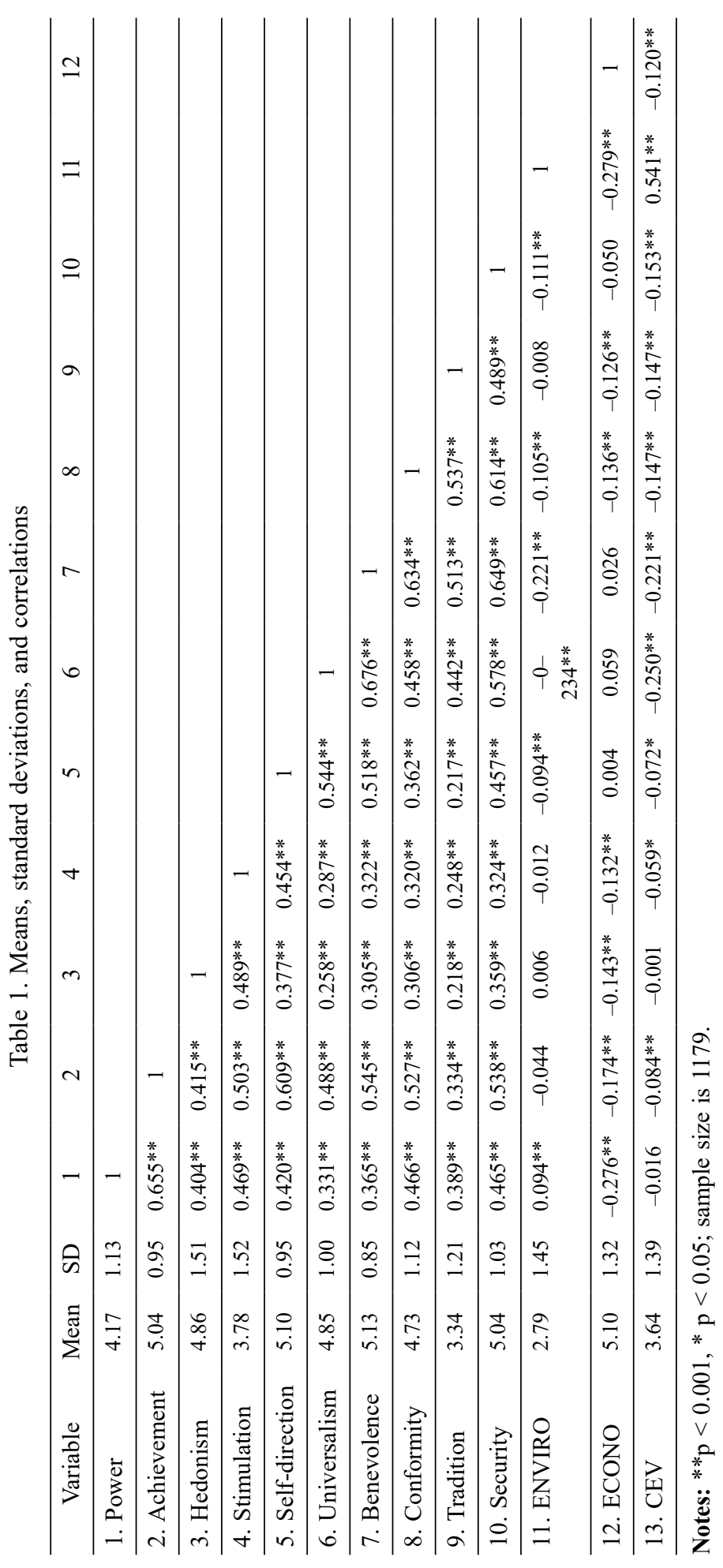


Table 2. Path analysis of managers' attitudes on EER

\begin{tabular}{lccccc}
\hline & R Square & $\begin{array}{c}\text { Unstanderdized } \\
\text { Coefficients }(\beta)\end{array}$ & $\begin{array}{c}\text { Standardized } \\
\text { Coefficients }(\beta)\end{array}$ & C.R. & $\mathrm{p}$ \\
\cline { 2 - 6 } & $72.3 \%$ & 0.945 & 0.872 & 10.276 & 0.000 \\
\hline Concern for environment & & -0.010 & -0.010 & -0.162 & 0.872 \\
\hline Concern for economic results & & &
\end{tabular}

Note: *dependent variable - EER.

Table 3. The direct effect of types of personal values on ATEN, ATEC, and EER

\begin{tabular}{ccccccccccc}
\hline & Power & $\begin{array}{c}\text { Achieve- } \\
\text { ment }\end{array}$ & $\begin{array}{c}\text { Hedo- } \\
\text { nism }\end{array}$ & $\begin{array}{c}\text { Stimu- } \\
\text { lation }\end{array}$ & $\begin{array}{c}\text { Self-di- } \\
\text { rection }\end{array}$ & $\begin{array}{c}\text { Univer- } \\
\text { salism }\end{array}$ & $\begin{array}{c}\text { Benevo- } \\
\text { lence }\end{array}$ & $\begin{array}{c}\text { Secu- } \\
\text { rity }\end{array}$ & Tradition & $\begin{array}{c}\text { Con- } \\
\text { formity }\end{array}$ \\
\hline EN & $-0.238^{* *}$ & $-0.074^{*}$ & $-0.075^{*}$ & 0.043 & -0.014 & $0.333^{* *}$ & $0.256^{* *}$ & -0.024 & $-0.211^{* *}$ & $0.092^{*}$ \\
\hline EC & $0.235^{* *}$ & $0.254^{* *}$ & $0.142^{* *}$ & 0.047 & $-0.137^{*}$ & $-0.219^{* *}$ & $-0.284^{* *}$ & -0.030 & $0.261^{* *}$ & 0.065 \\
\hline EER & $0.114^{*}$ & -0.035 & -0.015 & 0.026 & $-0.133^{*}$ & 0.058 & -0.070 & 0.029 & $0.188^{* *}$ & -0.045 \\
\hline
\end{tabular}

Notes: EN - environmental concern; EC - concern for economic results; EER - enterprise environmental responsiveness; ${ }^{* *} \mathrm{p}<0.001 ;{ }^{*} \mathrm{p}<0.05$.

Regarding the EER the results in Table 3 reveal that power and tradition are significantly and positively related, and self-direction is significantly and negatively related to them. On the other hand, the impact of managers' PV achievement, hedonism, stimulation, universalism, benevolence, security, and conformity is not significant. Based on findings about insignificant impact of these seven types of values, we reject Hypothesis 5.

Finally, we present results about mediating effect of managers' ATEC on the relationship between managers' PV and EER. Conditions for existence of mediation effect (Baron, Kenny 1986; Zhao et al. 2010) of ATEN are fulfilled (confirmed Hypotheses $1,3,4)$, while for the mediation effect of ATEC, one out of three conditions is fulfilled (hypotheses 4), since the effect of attitudes regarding economich results on EER is insignificant (Hypothesis 2 rejected). Even though, mediation effect of managers' ATEC can be considered (Judd, Kenny 1981). Table 4 summarizes the main findings about indirect effect of PV on EER, through considered ATEN and ATEC.

Considering the indirect effect of PV through manager's' ATEN on EER, the joint effect of values and mediator is much stronger, than the direct effect of PV on EER (power: direct effect $-\beta=0.105, \mathrm{p}<0.05$; indirect $=-0.201$; self-direction direct effect $-\beta=$ $-0.133, \mathrm{p}<0.001$; indirect $=-0.021$; tradition: direct effect $-\beta=0.167, \mathrm{p}<0.001$; indirect $=-0.132$ ).

Table 4. The indirect effect of types of personal values on EER

\begin{tabular}{lcccccccccc}
\hline Scenario & Power & $\begin{array}{c}\text { Achieve- } \\
\text { ment }\end{array}$ & $\begin{array}{c}\text { Hedo- } \\
\text { nism }\end{array}$ & $\begin{array}{c}\text { Stimula- } \\
\text { tion }\end{array}$ & $\begin{array}{c}\text { Self-di- } \\
\text { rection }\end{array}$ & $\begin{array}{c}\text { Univer- } \\
\text { salism }\end{array}$ & $\begin{array}{c}\text { Benevo- } \\
\text { lence }\end{array}$ & $\begin{array}{c}\text { Secu- } \\
\text { rity }\end{array}$ & $\begin{array}{c}\text { Tradi- } \\
\text { tion }\end{array}$ & $\begin{array}{c}\text { Con- } \\
\text { formity }\end{array}$ \\
\hline $\mathrm{EN}^{\mathrm{a}} \mathrm{M}^{\mathrm{a}}$ & -0.201 & -0.035 & -0.038 & 0.027 & -0.021 & 0.273 & 0.179 & -0.030 & -0.132 & 0.081 \\
\hline $\mathrm{EC}^{\mathrm{b}} \mathrm{M}^{\mathrm{b}}$ & -0.048 & -0.052 & -0.029 & -0.015 & 0.035 & 0.039 & 0.054 & 0.009 & -0.042 & -0.019 \\
\hline
\end{tabular}

Notes: a - standardized indirect effect of personal values on the EER - mediation variable is employees' ATEN; $b$ - standardized indirect effect of personal values on the EER - mediation variable is employees' ATEC. 
Hence, there is a positive mediation effect of ATEN for self-direction values, where the negative impact of self-direction values on EER, is turned into a positive impact. On the other hand, there is a negative mediation effect of ATEN for power values, where introduction of mediator variable reduces positive impact of power and tradition values on EER and turns it into a negative impact. Based on these results we can support Hypothesis 6 for power, self-direction and tradition values. Remaining dimensions of values do not support Hypothesis 6.

Indirect effect of PV, through managers' ATEN, on EER, the effect is stronger than direct effect of PV on EER (self-direction: direct effect $-\beta=-0.177, \mathrm{p}<0.001$; indirect $=$ 0.035 ; universalism: direct effect $-\beta=0.302, \mathrm{p}<0.001$; indirect $=0.039$ ). There is a positive mediation effect of ATEC on the relationship between self-direction values and EER, where the negative impact of self-direction values on EER, is turned into a positive impact. There is a negative mediation effect of ATEC on the relationship between universalism values and EER, where introduction of mediator variable reduces positive impact of self-direction values EER and turns it into a negative impact. Based on these results we can support Hypothesis 7 for universalism and self-direction.

In terms of the explained variance, results show that $72.3 \%$ of the variance in EER is accounted for by the variance in managers' ATEN and ATEC.

\subsection{Discussion}

This study reveals strong positive influence of employees' ATEN on EER, what is in accordance with previous environmental studies (Stern 2000; Blackburn 2007; Peet, Hartwick 2009; Haq, Alistair 2011). Additionally, the study results that ATEC negatively influences the EER, but the impact is very weak and insignificant, contradicts the previous studies, which reported about its significant negative influence (Kemmelmeier et al. 2002; Cordano et al. 2010; Marcus et al. 2015).

Regarding the influence of managers' ten dimensions of PV on their attitudes, results reveal positive impact of universalism and benevolence PV on employee's ATEC; that is in line with previous studies which emphasized concern for preservation of $\mathrm{NE}$ (Schwartz 1994) and importance of NE for employees (Karp 1996; Schultz, Zelezny 1999). The negative impact of power values on ATEN, also reflects general findings about the traditional relations between environmental and economic goals (Friedman 1970; Munda 1997; Hanley et al. 2007).

In terms of the direct impact of managers' PV it is evident that the impact of PV on EER is considerably weaker than the impact of employees' attitudes. This reflects stronger indirect effect of PV on EER. Those findings reflect the main cognitions from VABT, where it is outlined that individual's attitudes have stronger influence on individuals behavior than values do (Homer, Kahle 1988).

In terms of the indirect impact of PV on EER, it is evident that besides the significant mediating effect of ATEN and ATEC for several groups of values - i.e. both mediating variables importantly change the strength of direct impact of PV; they either reduce or enhance the impact of PV. This differs from the previous studies about relations between EER and ATEC (e.g. Friedman 1970). 


\section{Conclusions}

This paper reports about examination of the relationships between managers' PV, their ATEN, their ATEC, and EER. Regarding the impact of employees' ATEN reveals strong positive and significant influence on EER, while employees' ATEC negatively influences EER, but the impact is very weak and insignificant.

What about the direct influence of PV on considered variables, we confirm a significant influence of values on both groups of manager's attitudes and an insignificant influence on EER. In terms of the mediation effect of employees' ATEC it is evident that economic results have a negative mediation effect on the relationship between universalism and traditional values and EER, since they reduce the positive impact of both value groups on EER. This indicates a negative mediation effect of ATEC on relationship between employees' PV and EET.

Our findings suggest that the study of EER could be extended to include in theoretical consideration the employees' PV and attitudes regarding the issue related with additional theories, approaches, and viewpoints for managers of moral development and to counteract their pro-environmental behavior.

Practical implications enable developing a high EER. Policy recommendations include mainly the better understanding and management of PV, ATEN, ATEC, and EER in the enterprise. Cognitions about influence of PV on ATEN, ATEC and EER provide starting points for improvement of management of EER. Results could also be used for rethinking the previous researches about the pro-environmental behavior of enterprises about managers' capacity of EER, adequacy of their education and training programs, and possibilities for managers' ethical development.

In terms of future research, consideration of managers' PV can be extended to different typologies, and samples for consideration. The presented results are valid for a Slovenian sample; that can limit generalization of cognitions in other countries. Additionally, we could not consider all influential behavior factors. Another limitation is related to the self-assessment approach used for obtaining manager's answers, due to the possible effect of self-assessment on the results.

\section{References}

Agle, B. R.; Mitchell, R. K.; Sonnenfeld, J. A. 1999. Who matters to CEOs? An investigation of stakeholder attributes and salience, corporate performance, and CEO values, Academy of Management Journal 42(5): 507-525. http://dx.doi.org/10.2307/256973

Ajzek, I. 2001. Nature of operation of attitudes, Annual review of Psychology 52(1): 27-58. http://dx.doi.org/10.1146/annurev.psych.52.1.27

Alibeli, M.; Johnson, C. 2009. Environmental concern: a cross national analysis, Journal of International and Cross-cultural Studies 3(1): 1-10.

Arbuckle, J. L. 2007. Amos 16.0 user's guide. Chicago: Amos Development Corporation.

Baron, R. M.; Kenny, D. A. 1986. The moderator-mediator variable distinction in social psychological research: conceptual, strategic, and statistical considerations, Journal of Personality and Social Psychology 51(6): 1173-1182. http://dx.doi.org/10.1037/0022-3514.51.6.1173 
Baumol, W.; Litan, R.; Schramm, C. 2007. Good capitalism, bad capitalism and the economics of growth and prosperity. London: Yale University Press.

Bisnode. 2016. GVIN directory [online], [cited 30 February 2016]. Available from internet: www. gvin.com

Blackburn, W. 2007. The sustainability handbook: the complete management guide to achieving social, economic and environmental responsibility. London: Earthscan Publications.

Byrne, B. M. 2010. Structural equation modeling with AMOS. New York: Routledge.

Camelo-Odraz, C; Fernandez-Alles, M.; Ruiz-Navarro, J.; \& Sousa-Ginel, E. 2012. The intrapreneur and innovation in creative firms, International Small Business Journal 30(5): 513-535. http://dx.doi.org/10.1177/0266242610385396

Cordano, M.; Welcomer, S.; Scherer, R.; Pradenas, L.; Parada, V. 2010. A cross-cultural assessment of three theories of pro-environmental behavior: a comparison between business students of Chile and United States, The Journal of Environmental Education 41(4): 224-238.

http://dx.doi.org/10.1080/00958960903439997

Davis, G.; Whitman, M.; Zald, M. 2008. The responsibility paradox, Stanford Social Innovation Review 6(1): 31-37.

Dietz, T.; Fitzgerlad, A.; Shwom, R. 2005. Environmental values, Annual Review of Environment \& Resources 30(1): 335-372. http://dx.doi.org/10.1146/annurev.energy.30.050504.144444

Dunlap, R.; Gallup, G.; Gallup, A. 1993. Of global concern: results of the health of the planet survey, Environment 35(9): 7-39. http://dx.doi.org/10.1080/00139157.1993.9929122

Friedman, M. 1970. The social responsibility of business is to increase its profits, New York Times Magazine September 13: 32-33.

Glavas, A.; Kelley, K. 2014. The effects of perceived corporate social responsibility on employee attitudes, Business Ethics Quarterly 24(2): 165-202. http://dx.doi.org/10.5840/beq20143206

Gonzalez-Rodriguez, M. D.; Diaz-Fernandez, M. D.; Spers, V. R. E.; Leite, M. D. 2016. Relation between background variables, values and corporate social responsibility, Rae-Revista De Administracao De Empresas 56(1): 8-19. http://dx.doi.org/10.1590/S0034-759020160102

Hanley, N; Shogren, J. F.; White, B. 2007. Environmental economics. In theory and practice. New York: Palgrave MacMillan.

Haq, G.; Alistair, R. 2011. Environmentalism since 1945: the making of the contemporary world. London (UK): Routledge.

Ho, R. 2006. Handbook of univariate and multivariate data analysis and interpretation with SPSS. Boca Raton: Chapman \& Hall/CRC. http://dx.doi.org/10.1201/978142001111

Hofstede, G. 2001. Culture's consequences. Comparing values, behaviors, institutions, and organizations across nations. Thousand Oaks: SAGE.

Homer, P. M.; Kahle, L. R. 1988. A structural equation test of the value-attitude-behavior hierarchy, Journal of Personality and Social Psychology 54(4): 638-646.

http://dx.doi.org/10.1037/0022-3514.54.4.638

Hu, L.; Bentler, P. M. 1999. Cutoff criteria for fit indexes in covariance structure analysis: conventional criteria versus new alternatives, Structural Equation Modeling: a Multidisciplinary Journal 6(1): 1-55. http://dx.doi.org/10.1080/10705519909540118

Judd, C.; Kenny, D. 1981. Process analysis: estimating mediation in treatment evaluations, Evaluation Review 5(5): 602-619. http://dx.doi.org/10.1177/0193841X8100500502

Jung, C. 1921 [1971]. Psychological types. New York: Princeton University Press.

Karp, D. 1996. Values and their effect on pro-environmental behavior, Environment and Behavior 28(1): 111-133. http://dx.doi.org/10.1177/0013916596281006 
Kemmelmeier, M.; Krol, G.; Hun Kim, Y. 2002. Values, economics, and pro-environmental attitudes in 22 societies, Cross-Cultural Research 36(3): 256-285. http://dx.doi. org/10.1177/10697102036003004

Lin, C.; Yeh, J.; Hung, G. 2012. Internal impediments of organizational innovation: an exploratory study, Journal of Knowledge Economy 3(2): 185-198.

http://dx.doi.org/10.1007/s13132-011-0077-0

Marcus, J.; MacDonald, H. A.; Sulsky, L. M. 2015. Do personal values influence the propensity for sustainability actions? A policy-capturing study, Journal of Business Ethics 127(2): 459-478. http://dx.doi.org/10.1007/s10551-013-2032-4

Mullins, L. 2013. Management and organisational behaviour. London: FT Publishing International.

Munda, G. 1997. Environmental economics, ecological economics, and the concept of sustainable development, Environmental Values 6(2): 213-233. http://dx.doi.org/10.3197/096327197776679158

Nordlund, A.; Garvill, J. 2002. Value structures behind pro-environmental behavior, Environment and Behavior 34(6): 740-756. http://dx.doi.org/10.1177/001391602237244

Oreg, S.; Katz-Gerro, T. 2006. Predicting proenvironmental behavior cross-nationally - values, the theory of planned behavior, and value-belief-norm theory, Environment and Behavior 38(4): 462-483. http://dx.doi.org/10.1177/0013916505286012

Papagiannakis, G.; Lioukas, S. 2012. Values, attitudes and perceptions of managers as predictors of corporate environmental responsiveness, Journal of Environmental Management 100(1): 41-51. http://dx.doi.org/10.1016/j.jenvman.2012.01.023

Pastor, J. C.; Mayo, M. 2008. Transformational leadership among Spanish upper echelons: the role of managerial values and goal orientation, Leadership \& Organization Development Journal 29(4): 340-358. http://dx.doi.org/10.1108/01437730810876140

Peet, R.; Hartwick, E. 2009. Theories of development: contentions, arguments, alternatives. New York: Guilford Press.

Posner, B.; Munson, M. 1979. The importance of values in understanding organizational behavior, Human Resource Management 18(3): 9-14. http://dx.doi.org/10.1002/hrm.3930180303

Potocan, V.; Mulej, M.; Nedelko, Z. 2013. The influence of employees' ethical behavior on enterprises' social responsibility, Systemic Practice and Action Research 26(6): 497-511.

http://dx.doi.org/10.1007/s11213-013-9299-3

Potocan, V.; Nedelko, Z. 2015. A new socio-economic order: evidence about employees' values' influence on corporate social responsibility, Systems Research and Behavioral Science 32(2): 230-239. http://dx.doi.org/10.1002/sres.2264

Ralston, D.; Egri, C.; Reynaud E.; Srinivasan, N.; Furrer, O.; Brock, D.; et al. 2011. A twentyfirst century assessment of values across the global workforce, Journal of Business Ethics 104(1): 1-31. http://dx.doi.org/10.1007/s10551-011-0835-8

Ralston, D.; Egri, C.; Furrer, O.; Kuo, M.-H.; et al. 2014. Societal-level versus individual-level predictions of ethical behavior: a 48-society study of collectivism and individualism, Journal of Business Ethics 122(2): 283-306.

Raven, P.; Berg, L. 2003. Environment. New York: Wiley.

Rokeach, M. 1973. The nature of human values. New York: Free Press.

Schultz, W.; Gouviea, V.; Cameron, L.; Tankha, G.; Schmuck, P.; Franek, M. 2005. Values and their relationship to environmental concern and conservation behavior, Journal of Cross-Cultural Psychology 36(4): 457-475. http://dx.doi.org/10.1177/0022022105275962 
Schultz, W.; Zelezny, L. 1999. Values as predictors of environmental attitudes: evidence for consistency across 14 countries, Journal of Environmental Psychology 19(3): 255-265.

http://dx.doi.org/10.1006/jevp.1999.0129

Schwartz, S. 1994. Are there universal aspects in the content and structure of values?, Journal of Social Issues 50(4): 19-45. http://dx.doi.org/10.1111/j.1540-4560.1994.tb01196.x

Schwartz, S.; Cieciuch, J.; Vecchione, M.; Davidov, E.; Fischer, R.; Beierlein, C.; Ramos, A.; Verkasalo, M.; Lonnqvist, J. E.; Demirutku, K.; Dirilen-Gumus, O.; Konty, M. 2012. Refining the theory of basic individual values, Journal of Personality and Social Psychology 103: 663-688. http://dx.doi.org/10.1037/a0029393

Shafer, W. E.; Fukukawa, K.; Lee, G. M. 2007. Values and the perceived importance of ethics and social responsibility: the U.S. versus China, Journal of Business Ethics 70(3): 265-284.

http://dx.doi.org/10.1007/s10551-006-9110-9

Singhapakdi, A.; Vitell, S. J.; Rallapalli, K. C.; Kraft, K. L. 1996. The perceived role of ethics and social responsibility: a scale development, Journal of Business Ethics 15(11): 1131-1140. http://dx.doi.org/10.1007/BF00412812

Stern, P. 2000. Toward a coherent theory of environmentally significant behavior, Journal of Social Issues 56(3): 407-424. http://dx.doi.org/10.1111/0022-4537.00175

Stern, P.; Dietz, T. 1994. The value basis of environmental concern, Journal of Social Issues 50(3): $65-84$.

Sullivan, J. 2011. Increasing employee productivity: the strategic role that HR essentially ignores [online], [cited 20 February 2016]. Available from Internet: http://www.ere.net/2011/05/16/ increasing-employee-productivity-the-strategic-role-that-hr-essentially-ignores/

Thompson, S.; Barton, M. 1994. Ecocentric and anthropocentric attitudes toward the environment, Journal of Environmental Psychology 14(2): 149-157.

http://dx.doi.org/10.1016/S0272-4944(05)80168-9

Trevino, L.; den Nieuwenboer, N.; Kish-Gephart, J. 2014. (Un)ethical behavior in organizations, Annual Review of Psychology 65: 635-660.

http://dx.doi.org/10.1146/annurev-psych-113011-143745

Vitell, S. J.; Ramos, E.; Nishihara, C. M. 2010. The role of ethics and social responsibility in organizational success: a Spanish perspective, Journal of Business Ethics 91(4): 467-483.

http://dx.doi.org/10.1007/s10551-009-0134-9

Wang, L.; Juslin, H. 2011. The effects of value on the perception of corporate social responsibility implementation: a study of Chinese youth, Corporate Social Responsibility and Environmental Management 18(4): 246-262. http://dx.doi.org/10.1002/csr.250

Westing, A. 1996. Core values for sustainable development, Environmental Conservation 23(3): 218-225. http://dx.doi.org/10.1017/S0376892900038832

Wood, W. 2000. Attitude change: persuasion and social influence, Annual Review of Psychology 51: 539-570. http://dx.doi.org/10.1146/annurev.psych.51.1.539

Wynder, M.; Dunbar, K. 2016. Ethical values in the evaluation of corporate social performance, Managerial Auditing Journal 31(2): 180-196. http://dx.doi.org/10.1108/MAJ-09-2014-1092

Zhao, X.; Lynch, G. J.; Chen, Q. 2010. Reconsidering Baron and Kenny: myths and truths about mediation analysis, Journal of Consumer Research 37(2): 197-206.

http://dx.doi.org/10.1086/651257 
Vojko POTOCAN, PhD (in Business) is a Full Professor of Management and Organization at the Faculty of Economics and Business (FEB), University of Maribor (Slovenia). He has published over 450 texts, including 12 books, edited proceedings and textbooks. His main reseaerch interests are management, busines ethics, and CSR.

Zlatko NEDELKO, PhD (in Business) is an Assistant Professor at the University of Maribor, Faculty of Economics and Business, Department of Management and Organization. His main research interests are management, organization, business ethics, personal values, corporate social responsibility, transitional issues and innovativeness. He has published his articles in peer reviewed scholarly journals, book and conferences.

Valentina PELECKIENĖ, Doctor of social sciences (economics), works as Associated Professor at the Department of Social Economics and Management of Vilnius Gediminas Technical University. She is an author and co-author of more than 56 publications. Research interests include insurance, management, environment of organizations, and negotiations.

Kęstutis PELECKIS, Doctor of social sciences (economics), works as a Professor at the Department of Economics and Management of Enterprises of Vilnius Gediminas Technical University. He is the author and co-author of more than 100 publications. Research interests include the increase of the efficiency of business meetings and negotiations. 